\title{
Isolation of Schizophyllum commune from Rubberwood
}

\author{
Fitriyan Kurnia*, Periadnadi and Nurmiati \\ Laboratory of Microbiology, Biology Department, Faculty of Mathematics and Natural \\ Sciences, Andalas University, Limau Manis, West Sumatra-25163, Indonesia \\ *Corresponding author
}

\begin{tabular}{|l|}
\hline Key w o r d s \\
Edible wild \\
mushroom, \\
$\begin{array}{l}\text { Schizopyllum } \\
\text { commune, Media }\end{array}$ \\
\hline Article Info \\
\hline $\begin{array}{l}\text { Accepted: } \\
10 \text { November } 2020 \\
\text { Available Online: } \\
10 \text { December } 2020\end{array}$ \\
\hline
\end{tabular}

\section{A B S T R A C T}

Fungi are the first organisms to decompose organic substances found in plants and animals into simple elements. Some are edible and some contain poison. Edible wild mushrooms are one of the forest resources that have not been used optimally. As this is well known that wild mushrooms are only used by certain local or ethnic communities for food supply. One of the edible wild mushrooms is Schizophyllum commune. This fungus is a wood rot fungus and is usually found in various substrates such as dead tree trunks and branches. The use of mushrooms from nature can threaten the existence of wild mushrooms that grow in nature. The aim of this study was to obtain pure cultures of Schizophyllum commune. This study used a survey method and was analyzed descriptively. The results of this study indicate that the discovery of pure cultures of Schizophyllum commune on PDA (Potato Dextrose Agar) media with forms such as white fine threads and mycelium can fill the petri dish faster than previous studies and other fungal mycelium.

\section{Introduction}

Fungi play an important role in the survival of humans, animals, plants, and other microorganisms because fungi are the first organisms to decompose organic substances found in plants and animals into simple elements. Some mushrooms are edible and some contain poison. So far, edible mushrooms have been widely used as food and as ingredients for medicines. Various types of edible mushrooms have also been cultivated such as oyster mushrooms, ear mushrooms, edible mushrooms, and shiitake mushrooms. Wild mushrooms are also used by the community to be used as food and medicinal ingredients.

Edible wild mushrooms are one of the forest resources that have not been utilized optimally. According to Zhang et al., (2014), some mushrooms have the potential as a food 
supply to improve food security. As is well known, wild mushrooms are usually used by certain local or ethnic communities. This has been reported by Namera et al., (2017) that wild mushrooms are used by certain ethnic groups or tribes in the world as food for their survival.

One of the wild mushrooms that can be consumed is Schizophyllum commune. This fungus is a wood rot fungus that grows on various substrates such as dead stems and branches. Yim et al., (2013) reported that this fungus grows in both sub-tropical and tropical forests. According to Sornlake et al., (2017) usually found in tree waste or woodpiles. Takemoto et al., (2010) added that this fungus is found in the bark of dead trees, branching of dead trees is also found in living trees, but when this fungus grows, the tree will lose its survival.

Macrospkopis Schizophyllum commune has the characteristics of a small fruit body size, has a short stalk, the fruit body is also white and some are brown. This has been reported by Nion et al., (2012) macroscopically this mushroom has the characteristics of a small fruiting body, has a short stalk between 0.2$0.6 \mathrm{~cm}$ in length, a width of about $0.7-5 \mathrm{~cm}$ in the fruit body, and a grayish fruit body. Schizophyllum commune when the lamellae are dry or the fruiting body will split open and part of the lamella will roll upwards, this proves that this fungus can grow at high temperatures. Imtiaj et al., (2008) reported that the growth of this fungal mycelium requires a temperature of around $30^{\circ} \mathrm{C}-35^{\circ} \mathrm{C}$ and a $\mathrm{pH}$ of about 5 , so it can adapt well to high temperatures and low $\mathrm{pH}$ for mycelium growth. This fungus is also faster in the process of weathering wood compared to other fungi. Nasreen et al., (2015) stated that Schizophyllum commune produces enzymes to break down lignin found in wood which causes wood to rot.
Schizophyllum commune is found in various types of trees so that this fungus is widely used as a food ingredient, especially in Asian countries because it contains carbohydrates, fiber, and protein which are good for the body besides this fungus is also used as a medicinal ingredient (Krupodorova and Barshteyn, 2015). Oi and Liu (2000) added that this mushroom contains Schizophyllan which is an anti-cancer compound and an immune booster. Additionally, Mirfat et al., (2014) reported that the extract from Schizophyllum commune has properties to cure infections caused by bacteria and fungi so that it can be used as a potential antimicrobial agent.

Seeing the potential that this size fungus possesses, scientific research is necessary to obtain information on the possibility of cultivation as an effort to meet future food needs. This research was conducted in vitro where Schizophyllum commune was isolated from the fungal substrate and was placed on PDA (Potato Dextrose Agar) media. This study aimed to obtain in vitro fungal cultures.

\section{Materials and Methods}

\section{Sample collection}

A sampling of Schizophyllum commune was obtained by purposive sampling technique, the mushroom fruiting body was selected with a large size and wide lamellae. A sampling of this Schizophyllum commune by taking all parts of the Schizophyllum commune fruit body and samples of the substrate where this fungus grows. The sample was washed using sterile water and then dried.

\section{Media preparation}

Potato Dextrose Agar (PDA) is a medium commonly used in making pure cultures (F0). PDA (MERCK) media with a composition of 39 grams, added with $1 \mathrm{~L}$ of distilled water. 
The material is stirred and then put in the microwave until it boils.

\section{Isolation of Schizophyllum commune}

Place inoculation and hand sterilized with $70 \%$ alcohol. Sterilize the tools used such as tweezers, knives, spatulas by dipping in $70 \%$ alcohol and heating them over a bunsen fire. Cool before use. Select the body part of the mushroom such as lamella cut using a knife aseptically (Utoyo, 2010). Take the explant pieces using tweezers and place them in a Petri dish containing PDA medium. Incubate until white mycelium grows. If contaminant microbes grow, do purification through cork borer mycelium grows, put it back on the new agar medium aseptically.

\section{Parameter}

The growth of Schizophyllum commune mycelium on agar was observed during the day the mycelium filled the Petri dishes and the thickness of the mycelium, as well as the fungal mycelium morphology, were observed.

\section{Data analysis}

Data analysis was performed in this study using descriptive methods to explain the growth of the mycelium Schizophyllum commune.

\section{Results and Discussion}

Based on field data, Schizophyllum commune is found and grows wild in various types of trees. This fungus is a fungus that can be consumed and grows saprophytic on tree trunks such as rubber, mango, and other tree species. The location where the fungus was found was in the form of a community rubber plantation. At that location, there is a pile of dead and rotten rubberwood. This has been previously reported by Takemoto et al.,
(2010) Schizophyllum commune is found in the bark of dead trees, tree branches and is also found in living trees but when this fungus grows, the tree loses its survival. So far, people have used this fungus as food. They look for mushrooms during the rainy season in rubber plantation areas where logs have died and are starting to rot. The search for mushrooms is carried out to meet daily food needs.

Based on research in the macroscopic field this fungus has characteristics with a small fruit body size, a short fruiting body, the surface of the fruiting body or lamellae hairy, and matte white, some are brownish. At the beginning of the growth of this fungus, the fruiting body is white after which the fruiting body will be brownish. This has been reported by Nion et al., (2012) which states that this fungus has a small fruiting body, has a short stalk with a size of 0.2-0.6, has a grayish fruit body, and the width of the body is about 0.7-5 $\mathrm{cm}$. Also, if it is dry, the lamellae of Schizophyllum commune will be separated or torn and half of the separated lamella will roll-up.

The use and utilization of mushrooms by relying on natural production are unlikely to meet the needs of the community. The sustainable use of mushrooms from nature can threaten the existence of mushrooms that grow wild in nature. Thus, mushroom cultivation is one way to meet the needs of the community as the first step in cultivating consumption mushrooms that grow wild in nature.

A pure culture is a result of in vitro culture of the parent fungal tissue in a medium. Schizophyllum commune culture was carried out to obtain F0 seeds. Fungal explants were incubated until the entire surface of the media was filled with fungal mycelium. In in vitro culture, the synthetic medium used to culture 
Fungus Kukur is the basic medium of Potato Dextrose Agar (PDA) which is carried out aseptically. Chang and Milles (2004) reported in vitro culture of fungi using the PDA medium because it is the most common medium for growing cultivated mushroom mycelium. Watling and Moore (1994) added that mycelium culture can be done by in-vitro from a fragment of an adult structure such as a piece of the fruiting body because the constituent cells in the fungal fruiting body are totipotent. The formation of the fruiting body to the surface of the media comes from a collection of mycelium.

The growth of Schizophyllum commune mycelium growing on PDA media only took 4 days after inoculation to fill the petri dish with a diameter of $9 \mathrm{~cm}$. Compared with previous studies conducted by Rosnan et al., (2019) in his research that mycelium growth requires 10 days after inoculation to fill the petri dish. Sumarsih (2010) added that oyster mushroom mycelium growing on PDA media took 12 days to fill the petri dish, this proved that the growth of Schizophyllum commune mycelium was faster than that of other fungi mycelium.

Schizophyllum commune grows on day 2 after inoculation which is initially thin and then thickens on day 4 due to the branching of the mycelium, from which these branches form other branches. According to Chiu (1993), the mycelium is multinucleate and has septa, so it can grow to form branches. The existence of proper nutrition in a medium also supports the growth of mycelium. The following are the results of pure Schizophyllum commune culture on PDA media from the initial inoculation until the mycelium fills the entire surface of the media.

Based on Figure 1, the growth of Schizophyllum commune mycelium has increased on the 2nd day after inoculation, it is suspected that at the beginning of growth after inoculation, there is a process of adaptation adjustment to the media used and the formation of extracellular enzymes. This has been previously reported by Pinasthika et al., (2018) Mushroom mycelium on the first day grown in a medium with complex carbohydrate compounds requires adaptation and has a longer time to break down the components used for energy synthesis.

Based on observations on fruiting tissue or explants inoculated on PDA media, it grows white. The fungal mycelium grows on the surface of the PDA media and fills the entire surface of the media as long as nutritional needs are met and there is no contamination from other microorganisms. It has been explained by Deacon (2006) that mushroom mycelium is generally very efficient and adaptive in absorbing nutrients for its needs. Sagala et al., (2015) added that to produce good quality F0 seeds, it requires a nutritious planting medium and is protected from contamination.

Fig.1 Growth of mycelium Schizophyllum commune on PDA media (A) Day 1, (B) Day 2, (C) Day 3, (D) Day 4
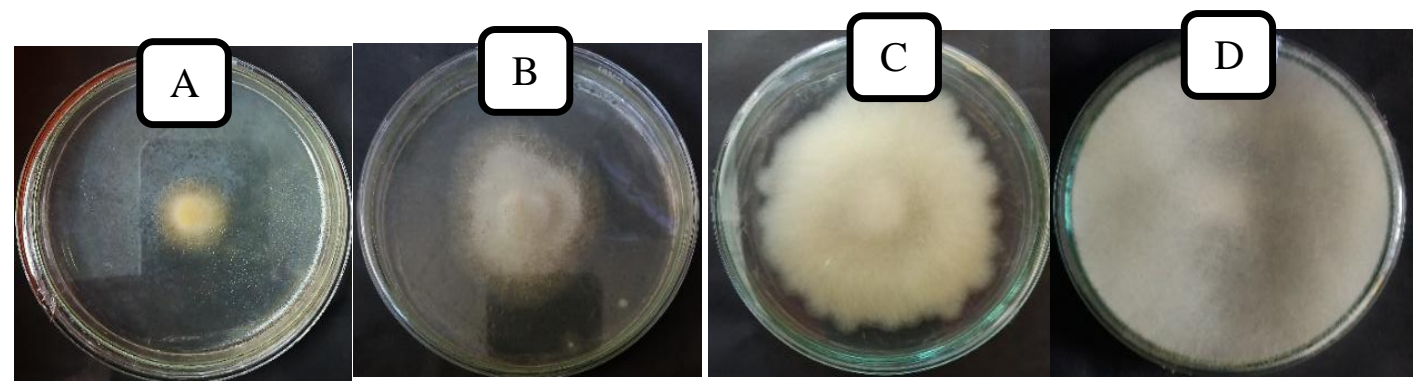
Schizophyllum commune when cultured has white mycelium and looks solid. This fungus mycelium is difficult to separate from agar media. Macroscopically, this mushroom mycelium is shaped like a feather or fine white threads. The beginning of the growth of this fungal mycelium grows thin on the surface of the media and after filling the entire surface of the media, the mycelium will look thicker. The growth rate of this fungal mycelium is influenced by the genetic characteristics of the fungus used as the explant, apart from being influenced by the genetic properties of the fungal body, the growth rate of the mycelium is also influenced by the suitability of the fungi's mycelium to nutrition and the environment.

Based on the research that has been carried out, it was concluded that pure fungal culture of size on PDA (Potato Dextrose Agar) media with a shape such as fine white threads and mycelium can fill the petri dish faster than previous studies and other fungal mycelium.

\section{References}

Chang, S, and P.G. Milles. 2004. Mushroom: Cultivation, Nutritional Value, Medicinal Effect, and Environmental. CRG Press. New York.

Chiu, S.W. 1993. Evidence for a haploid lifecycle in Volvariella volvacea from microspectrophotometric measurements and observations of nuclear behaviour. Mycol. Res. 97(12): 1481-1485.

Deacon, J. W. 2006. Fungal Biology. Blackwell Publishing. Australia

Imtiaj, A, C. Jayasinghe, G.W. Lee, H.Y.Kim, M.J. Shim, H. S. Lee, H. Hur, M.W. Lee, U.Y. Lee and Lee, T.S. 2010. Physicochemical Requirement for the Vegetative Growth of Schizophyllum commune Collected from Different Ecological Origins. Mycobiology, 36(1),
34. https://doi.org/10.4489/myco.2008. 36.1.034

Krupodorova, T. A., and V. Y Barshteyn. 2015. Amaranth Flour as a New Alternative Substrate for Schizophyllum commune Fr.: Fr. and Cordyceps sinensis (Berk.) Sacc. Growth Journal of Siberian Federal University. Biology $132-44$

Mirfat, A. H. S., A. Noorlidah., and S. Vikineswary. 2014. Antimicrobial activities of split gill mushroom Schizophyllum commune Fr. American Journal of Research Communication Vol 2(7)

Namera et al., 2017. Edible wild mushrooms of the Western Ghats: Data on the ethnic knowledge. Data in Brief 14 (2017) 320-328

Nasreen, Z., Jabeen, S., Yasmeen, A., Shafique, M., Usman, S., \& Ali, S. 2015. Original Research Article Optimization of Sub-Merged Culture Conditions for Biomass Production in Schizophyllum commune, a Medicinal Mushroom. International Journal of Current Microbiology and Applied Sciences, 4(2), 258-266.

Nion Y,A., A Agus Djaya., E Marlina Kadie., Lune., Sumarlan and C Hanny Wijaya. 2012. Siklus Hidup Jamur Konsumsi Lokal Kulat Kritip (Schizophyllum commune) Pada Daerah Bergambut dan Daerah Bertanah Mineral sertaPotensi Nutrisinya. Jurnal Biologi Indonesia 8 (2).

Oi, FEC. and F. Liu. 2000. Immunomodulation and Anti-Cancer Activity of Polysaccharide- Protein Complexes. Curr. Med. Chem. 7, 715729.

Pinasthika, N.P., R. Arbianti, T.S. Utami dan H. Hermansyah. 2018. Effect of Medium and Incubation Time on Production Of AA, DHA and EPA from 
Aspergillus oryzae By Solid State Fermentation. IOP Conf. Series: Earth and Environmental Science

Rosnan, N.D, N.L. Chuen, and Ngadin, A.A. 2019. First record of in vitro growth evaluation of wild mushroom, Schizophyllum commune from Pulau Kapas in Malaysia. Asian J Agric \& Biol.;7(4):602-609

Sagala, L.A.B., E. Aprilina., A. Sonip., M. Risanti, Irzaman. 2015. Penumbuhan Miselium Jamur Tiram Putih (Pleurotus ostreatus) Pada Media Sorgum dan Analisis Fourier Transform Infrared (FTIR ). Seminar Nasional Fisika. 5:5156.

Sornlake.W, P. Rattanaphanjak., V. Champreda., L. Eurwilaichitr., S. Kittisenachai., S. Roytrakul, T. Fujii and H. Inoue. 2017. Characterization of cellulolytic enzyme system of Schizophyllum commune mutant and evaluation of its efficiency on biomass hydrolysis. Bioscience, Biotechnology, and Biochemistry, Vol. 81, No. 7, 12891299

Sumarsih, S. 2010. Untung Besar Usaha Bibit Jamur Tiram. Penebar Swadaya. Depok Takemoto S., H Nakamura., Erwin., Y
Immamura., and $\mathrm{T}$ Shimane. 2010. REVIEW Schizophyllum commune as a Ubiquitous Plant Parasite. JARQ 44 (4), $357-364$

Utoyo, N. 2010. Bertanam Jamur Kuping di Lahan Sempit. PT AgroMedia Pustaka: Jakarta

Watling, R., D. Moore. 1994. Moulding moulds into mushrooms: Shape and form in the higher fungi. In: Shape and Form in Plants and Fungi (D.S. Ingram and A. Hudson, eds.), pp. 270-290. Academic Press, London.

Yim, H,S., F. Yee Chye., V. Rao., J. Yin Low., P. Matanjau., S. Eng How., and C. Wai Ho. 2013. Optimization of Extraction Time and Temperature on Antioxidant Activity of Schizophyllum commune Aqueous Extract Using Response Surface Methodology. J Food Sci. Technol., 50(2): 275-283.

Zhang, Y., W. Geng, Y. Shen, Y. Wang and Y. Dai. 2014. Edible mushroom cultivation for food security and rural development in China: bio-innovation, technological dissemination and marketing. Sustainability. 6: 2961-2973

\section{How to cite this article:}

Fitriyan Kurnia, Periadnadi and Nurmiati. 2020. Isolation of Schizophyllum commune from Rubberwood. Int.J.Curr.Microbiol.App.Sci. 9(12): 1202-1207. doi: https://doi.org/10.20546/ijcmas.2020.912.147 